Journal of Language \& Translation 9-1

March 2008, 7-40

\title{
Translation of Poetry: Towards a Practical Model for Translation Analysis and Assessment of Poetic Discourse
}

\author{
Hossein Vahid Dastjerdi \\ University of Isfahan \\ Haadi Hakimshafaaii \\ Bojnord University \\ Zahra Jannesaari \\ Tehran University
}

\begin{abstract}
Among translation issues, poetry translation is the most problematic area challenging both translators and authorities in the field of translation studies. Translation of poetry as a yet unanalyzed 'black box' (Francis 2006) has been a much debated issue since olden times, with many pros and cons and dichotomist reasoning as to its possibility or impossibility. This is due to the high cultural prestige of poetry which requires time, effort and ingenuity to translate traditional rhyme, rhythm structures and the figurative language involved. In the present study, a Persian piece of poetry by the contemporary Iranian poet, Musavi Garmaroodi, A. (1984) and its English translation by Vahid, D. H. (2006) will be focused upon and descriptively analyzed at both linguistic and extra linguistic levels.
\end{abstract}


The aim is to identify the formative elements of versified discourse in the source and target texts (ST/TT) and to arrive at a tentative model of translation analysis which can serve as a measure for translation assessment of poetic genre.

Keywords: translatability, textual analysis, extra-textual analysis, translation assessment, poetic discourse

\section{Introduction}

\subsection{Definition and Process of Translation}

Many a different definition has been proposed for the simple concept termed 'translation'. Let's get started with Nida (1964) who defines translation as a process of finding the closest natural equivalent of source language in target language in terms of massage and style, and proceed to Catford (1965) who believes that translation is the replacement of the source language textual elements by the target language textual elements. Toury (1978), cited in Lefevere (1992), holds the view that translation is a kind of activity which inevitably involves at least two languages and two cultural traditions whereby an original text is rewritten by the translator into a different language. Newmark (1988) considers translation as a craft in which the translator tries to replace a written massage in one language by the same massage in another language. Munday (2002), as a more recent authority, is of the opinion that in translation process the translator changes an original written text in original verbal language into a written text in a different verbal language. Among all these, just to mention a few, Toury's definition is a culturally-oriented one focusing on the socio-cultural patterns of source and target languages.

Concerning the translation process, a very general view is that in translation there are two processes involved: the translator analyzes 
the SL form in order to find out the meaning and second the translator produces, or chooses proper TL form for this meaning (Mollanazar 2005). It should be added that since each language has a distinctive form and pattern of its own and there is thus no one- toone relationship between any two languages, the same meaning may be expressed in another language in quite a different grammatical or lexical form.

\subsection{Types of Translation}

Based on their definition for translation, the above-mentioned authorities propose their specific categorization of translation types. Catford (1965) introduces three types of translation in terms of three criteria:

1. The extent of translation (full translation vs. partial translation)

2. The grammatical rank at which the translation equivalence is established (rank-bound translation vs. unbound translation)

3. The levels of language involved in translation (total translation vs. restricted translation)

Nida (1964) categorizes translation into two types: formal translation vs. dynamic translation. In formal translation, he asserts, the way meaning was conveyed is shown, that is, the style of the original is preserved. Dynamic translation, he believes, is a translation principle according to which translators seek to translate the meaning of the original in such a way that the TL wording will trigger the same impact on the target audience as the original wording did upon the source language audience. He further states that in this type of translation usually the form of the original text is changed.

Newmark (1988) proposes two types of translation: semantic vs. communicative. He states that while communicative translation 
attempts to produce on its readers an effect as close as possible to that obtained on the readers of the original, semantic translation attempts to render as closely as the semantic and stylistic structures of the second language allow, the exact contextual meaning of the original. As to communicative translation, he believes that equivalent effect is illusory because if the text is out of TL space and time the equivalent effect can not be produced.

A cursory glance at the above descriptions of translation types brings us to Munday's (2002) statement that Newmark's communicative and semantic translations are similar to Nida's dynamic and formal equivalence.

\subsection{Translation of Poetry}

While translating verse

You crash through a wall

And with a bloody face

You are suddenly on the stage

Lit up by thousands of watts

Facing thousands of eyes

After having made your way

Through the brick, like a stream

(Slutsky in Friedberg 1997: 118)

Poetry, according to Alexander Pope, has been said to consist of "what oft was thought, but ne'er so well expressed" (1711). Thus, poetry seems to lie on a continuum with one end attached to human feelings and emotions, which can only be sensed, not given expression to; for how can we say how much we enjoyed a poem? The other side attached to his means of communication, i.e. language; hence the controversial relationship between language and mind.

The issue of the translatability of poetry has long been a heated 
debate among scholars. Some scholars believe that what is lost in translation is the poetry, while others state that all meanings are translatable and only the form of poetic discourse is lost in translation. There are still other scholars who believe that poetry translation is possible only if both the meaning and style of the source text are kept intact in the target language. Below is a sketch of the arguments of both groups:

According to Frost (1969), the main characteristic of poetic discourse that distinguishes it from common discourse is that in poetry form and content can not be separated. Content is highly language-bound and this is what makes poetic translation of poetry more difficult than other types of translations. He believes poetry is what is lost in translation. Nabakof cited in Giblett (1987) compares poetry translation to beheading, insulting the dead and a parrot's scream, and Roman Jacobson (1960) states that poetry is by definition untranslatable.

As to those who take an almost positive stance concerning the translation of poetry, Boase-Beir and De Beauground cited in Connally (1991) believe that translation of poetry can be successful only if both style and content are transferred. Holmes (1970) who has a descriptive view towards translation believes that there may be as many different translations of the same poem as the number of translators. He adds that while the translation of a poem is never equal to the original, any text including a poetic one has many interpretations and therefore many possible translations. Nair (1991) believes that poetry is an imaginative expression of a poet's feelings and experiences and its translation must be a faithful transference of the poet's ideas. A poetry translator should, therefore, strive for accuracy and this makes the translator's fluency of expression indispensably difficult. Lefever (1992) who takes side with the issue introduces a number of methods for translation of poetry; namely, phonological translation, literal translation, rhythmic translation, translation into prose, translation into rhymed poetry, translation 
into poetry without rhyme (blank verse), and interpretive translation. He states that in the past most translators translated poetry into rhymed poetry but today they translate poetry into prose. He adds that some translators translate only the meaning at the price of the form but sometimes translators get help from the poet to create a new work.

A final word here is that the possibility of poetry translation does not mean that all aspects of a poem are translatable in practice, since each language has its own lexical and structural patterns which in some cases resist imitation in other languages. However, getting close to the original text as much as possible is not a far-fetched aspiration, as the past has witnessed great achievements in crosscultural renderings of poetic masterpieces of a language to other languages. Nicholson's (1962) translation of Rumi's Mathnawi, Arberry's (1947) Fifty Poems of Hafiz, and Rehatsek's (1964) The Gulistan of Sádi are just a few to mention.

\section{Method}

Based on the aim of the present study, a translated version of Garmaroodi's poem (see Appendix), will be compared and contrasted with its Farsi original at both textual and extra-textual levels. Dealing with the object (product/translated text) rather than the subject (processes employed by the translator) of translation, this procedure first incorporates the look or form of the text at the textual level under three major headings; namely, music, rhyme and tropes. In this section, the two texts are examined in terms of words, images, stanza and structural patterns, literary devices, and type of the poem. Moreover, the linguistic differences and similarities between the ST and TT are elaborated. Also, the aura or tone of the text is examined and exemplified with respect to the genre of the poem. Finally, the message of the text is focused. 
At the extra-textual level, the ST and TT are discussed and scrutinized in their cultural framework. Here, culture-specific terms are explained and the covert corners of individual words and phrases in the ST will be demystified with an eye on the existence or nonexistence of their equivalents in the TT. Eventually, based on the detailed discussion of the translated text, a product-oriented model for translation analysis will be proposed.

\section{Analysis and Discussion of Data}

\subsection{Textual Analysis}

Form (linguistic features) has been defined as the actual words, phrases, clauses, paragraphs, etc., which are spoken or written. In other words, it is the structural part of language which is seen or heard. In literary criticism, form often refers to a literary type (lyric, ode, short story, etc.) or to patterns of rhythm, rhyme, lines and stanzas. In this study, the material to be analyzed is a Persian piece of modern poetry or blank verse which is devoid of any meter. Therefore, rhythm is not focused upon in the analysis of the translated text.

\subsubsection{Music}

In the first stanza of the Persian poem there is some use of alliteration. The words مهر (/mahr/) andar/) make consonance. The vowel /aa/ is a case of assonance in words

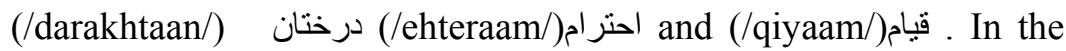
English translation, more alliterations are seen: "st" in standing/straight, " $\mathrm{m}$ " in marriage gift/mother, mirrors/modesty and martyrdom/morning and "c" in colored/crimson. The vowel "/o/" too is repeated in words aurora/your/alter/morning/dawn, making 
14 Towards a Practical Model for Translation Analysis and Assessment of Poetic Discourse

assonance.

In the second stanza of the Persian poem there are three cases of

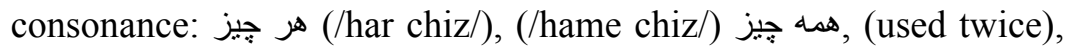
and تواويد (/to/), ترو (/taraavid/). The vowel /i: / is a case of assonance in the words يزيدى (/Yazidi/), حسينى (/Hosaini/). The vowel /aa/ too is a case of assonance in words (/aabhaa/) (آبها: (/sanghaa/). In contrast, in the second stanza of the English translation there is only one case of assonance: similar vowels "/ə/ and /e/" in a/elevated. There are two cases of consonance too: "n" sound in now/neighbor, "s" sound in sword/struck.

In the third stanza of the source text there are two cases of consonance: مرك (/marg/),(/me'yaar/) معيار,(/khunbahaayat/) (/khunat/), and one case of assonance, i.e. vowel /aa/

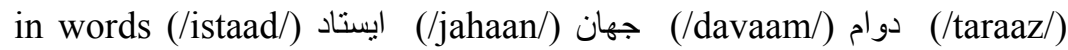

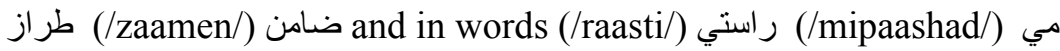
جهان (jahile in the corresponding English stanza there are 8 cases of consonance and one case of assonance: "d" sound in death/ridiculous, "t" sound in turn/stay/to, "w" sound in with/worth, will/world and word/with, "s" sound in stand/still, "b" sound in blood/but, "l" sound in blood/blood-worth/level, and vowel/o / in words sword/your/.

In the forth stanza of the Persian poem there are four

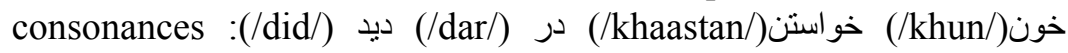

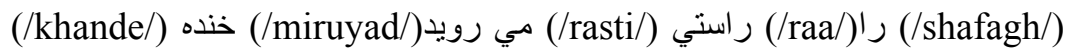

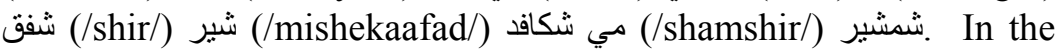
corresponding English translation there are three cases of consonance: "w" sound in waters/when, "s" and " $\mathrm{t}$ " sounds in satiate/stones/standing/straight, and "s" sound in sanguine/skies. The vowel /ai/ is a case of assonance in skies/smile/rise.

In the fifth stanza of the Persian poem there are nine cases of

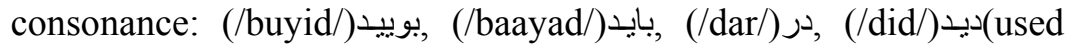

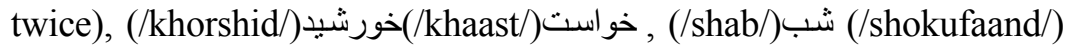

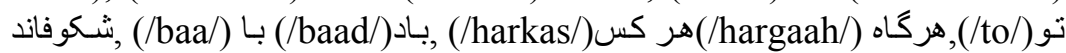




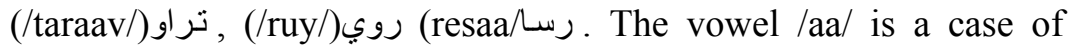

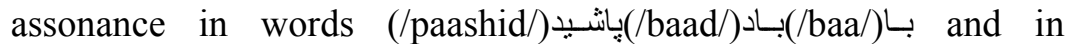

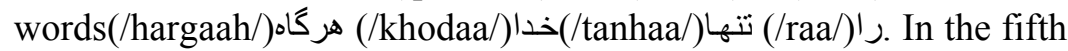
stanza of the corresponding English translation there are seven consonances: "s" sound in seen/smelled and sun/sought, "b" sound in bowers/bright/breeze, "h" sound in his/hands/whoever, " $\mathrm{f}$ " sound in from/finger, "s" sound in sun/say/so, and " $t$ " sound in tis/true.

In the sixth stanza of the Persian poem there are seven

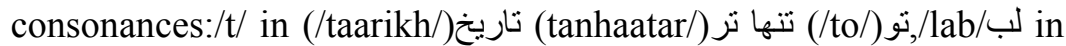

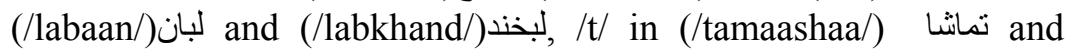

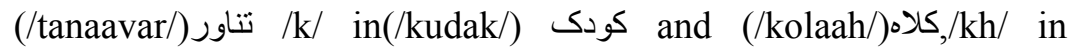

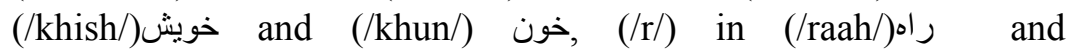

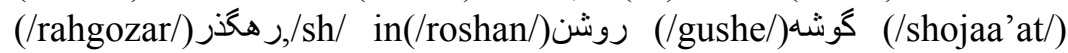
شجاعت. The vowel/aa/ is just one case of assonance in words

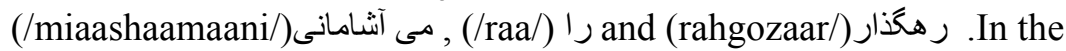
sixth stanza of the corresponding English translation there are five consonances: "c" sound in courage/conscience, "s" sound and " $\mathrm{c}$ " sound in sincerity/sweet/stand/still, so/sky/stature, "h" sound in head/hat, and "c" sound again in cup/culture. Table 1 below shows the identified cases of alliteration in source and target texts:

Table 1. Textual Analysis: Alliteration in Source and Target Texts

\begin{tabular}{|c|c|c|c|c|c|}
\hline stanza & $\begin{array}{c}\text { Type of } \\
\text { alliteration }\end{array}$ & English & Persian & $\begin{array}{l}\text { No. of cases } \\
\text { in English }\end{array}$ & $\begin{array}{c}\text { No. of cases in } \\
\text { Persian }\end{array}$ \\
\hline \multirow[b]{2}{*}{1} & Assonance & $\begin{array}{l}\text { Aurora/your/ } \\
\text { Morning/ } \\
\text { dawn }\end{array}$ & $\begin{array}{l}\text { درختان/احتر/ام/قيام/(ghiaam/ehteraam/der } \\
\text { akhtaan) }\end{array}$ & 5 & 3 \\
\hline & Consonance & $\begin{array}{l}\text { Standing/ } \\
\text { straight/ } \\
\text { Marriage gift/ } \\
\text { mother/ } \\
\text { Colored/ } \\
\text { crimson } \\
\text { Mirrors/ } \\
\text { modesty } \\
\text { Martyrdom/ } \\
\text { morning }\end{array}$ & 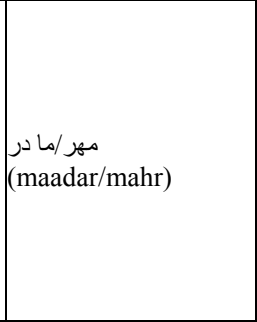 & 10 & 2 \\
\hline
\end{tabular}


16 Towards a Practical Model for Translation Analysis and Assessment of Poetic Discourse

\begin{tabular}{|c|c|c|c|c|c|}
\hline stanza & $\begin{array}{c}\text { Type of } \\
\text { alliteration }\end{array}$ & English & Persian & $\begin{array}{c}\text { No. of cases } \\
\text { in English }\end{array}$ & \begin{tabular}{|c|}
$\begin{array}{c}\text { No. of cases in } \\
\text { Persian }\end{array}$ \\
\end{tabular} \\
\hline \multirow[b]{2}{*}{2} & Assonance & a/elevated & $\begin{array}{l}\text { حسينى/يزيديد/Hosaini) } \\
\text { (Yazidi/ابها/سنكا } \\
\text { (sanghaa/aabhaa) }\end{array}$ & 2 & 4 \\
\hline & Consonance & $\begin{array}{l}\text { Now/neighbor } \\
\text { Sword/struck }\end{array}$ & 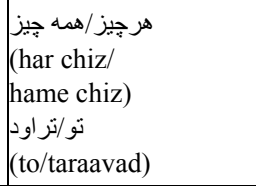 & 4 & 4 \\
\hline \multirow[b]{2}{*}{3} & Assonance & Sword/your & 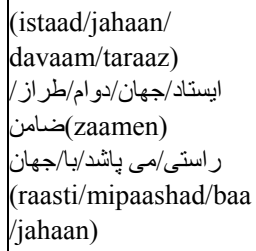 & 2 & 9 \\
\hline & Consonance & $\begin{array}{l}\text { Death/ } \\
\text { ridiculous } \\
\text { Turn/stay/to } \\
\text { blood/blood } \\
\text { worth/level } \\
\text { With/worth } \\
\text { Will/world } \\
\text { blood/but } \\
\text { Word/with } \\
\text { stand/still }\end{array}$ & 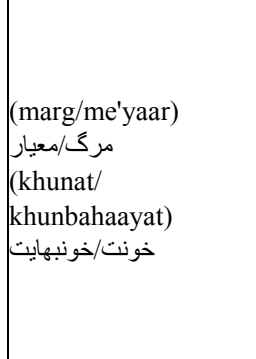 & 18 & 4 \\
\hline \multirow[b]{2}{*}{4} & Assonance & $\begin{array}{l}\text { Skies/smile/ } \\
\text { rise }\end{array}$ & - & 3 & 0 \\
\hline & Consonance & $\begin{array}{l}\text { Waters/when } \\
\text { Satiate/stones/ } \\
\text { standing/ } \\
\text { straight } \\
\text { Sanguine/ } \\
\text { skies }\end{array}$ & 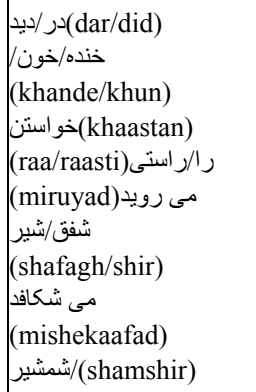 & 8 & 12 \\
\hline
\end{tabular}




\begin{tabular}{|c|c|c|c|c|c|}
\hline stanza & $\begin{array}{c}\text { Type of } \\
\text { alliteration }\end{array}$ & English & Persian & $\begin{array}{l}\text { No. of cases } \\
\text { in English }\end{array}$ & $\begin{array}{c}\text { No. of cases in } \\
\text { Persian }\end{array}$ \\
\hline & Assonance & - & 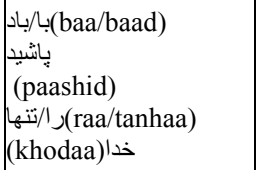 & & \\
\hline 5 & Consonance & $\begin{array}{l}\text { Seen/smelled } \\
\text { Sun/sought } \\
\text { Bowers/ } \\
\text { bright/ } \\
\text { breeze } \\
\text { Hands/his/ } \\
\text { whoever } \\
\text { From/finger } \\
\text { Sun/say/so } \\
\text { Tis/true }\end{array}$ & 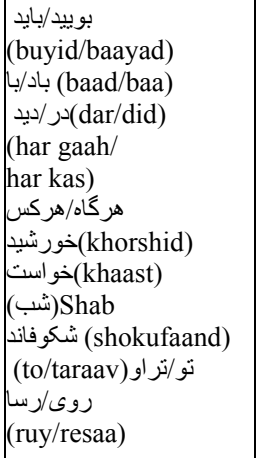 & 17 & 16 \\
\hline \multirow[b]{2}{*}{6} & Assonance & - & 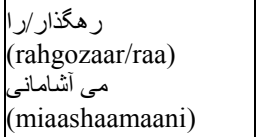 & 0 & 3 \\
\hline & Consonance & $\begin{array}{l}\text { Courage/ } \\
\text { conscience } \\
\text { Sincerity/ } \\
\text { sweet/ } \\
\text { stand/ } \\
\text { still } \\
\text { So/sky/stature } \\
\text { Head/hat } \\
\text { Cup/culture }\end{array}$ & 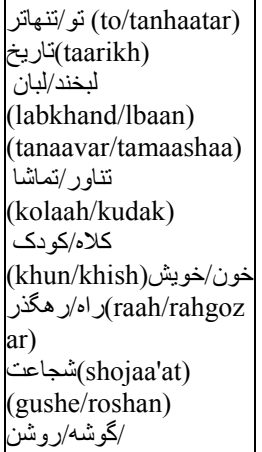 & 13 & 16 \\
\hline
\end{tabular}




\subsubsection{Rhyme}

In the first stanza of the Persian poem there are no rhymes, but in the corresponding English translation, sentences are rhymed. Examples are: lover/honor/water/mother, dignity/modesty, alter/prayer.

In the second stanza of the Persian poem some sentences are

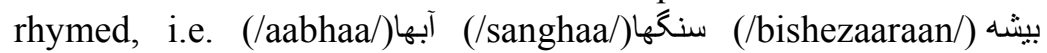

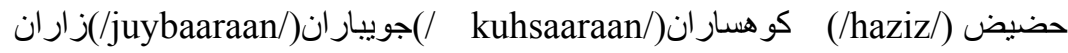
(عزيز)/aziz. In the second stanza of the English translation, which/Ditch/rich, side/abide, prize/otherwise, and red/instead rhyme.

In the third stanza of the Persian poem there are no rhymes. In the English translation, ridiculous/worthless, way/stay, will/still, and ahead/fed rhyme.

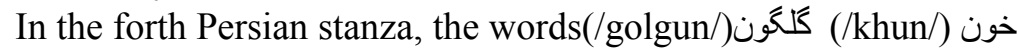

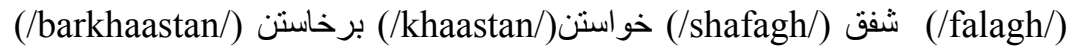
فلق rhyme, while in the English translation, the pairs view/you, satiate/straight, through/do, skies/rise produce the same sound.

In the fifth stanza of the source text, only (/buyid/,

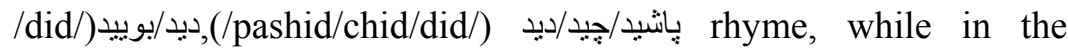
corresponding English translation we see more rhyming terms, i.e. seen/mean, twilight/night/bright, Divinity/reality, whoever/finger, you/true, say/ray. In the last stanza of the source text, only the حقيقت (/shojaa'at/) and (/haghighat/) شجاعت ,صداقت) words(/sedaaghat rhyme, while in the corresponding English translation there are many rhyming words such as: courage/edge, will/still, high/sky/eye, me/baby, history/humanity, sea/see. Table 2 below clearly demonstrates the difference between source and target texts in terms of rhyming schema which carries part of the beauty of poetic discourse. 
Table 2. Rhyme Scheme in Source and Target Texts

\begin{tabular}{|c|c|c|c|c|}
\hline stanza & Persian & English & $\begin{array}{c}\text { No. of rhymed } \\
\text { terms in } \\
\text { English }\end{array}$ & $\begin{array}{l}\text { No. of } \\
\text { rhymed } \\
\text { terms in } \\
\text { Persian }\end{array}$ \\
\hline 1 & - & $\begin{array}{c}\text { Lover/honor/water/ } \\
\text { Mother Dignity/modesty } \\
\text { alta 'r/prayer }\end{array}$ & 8 & 0 \\
\hline 2 & 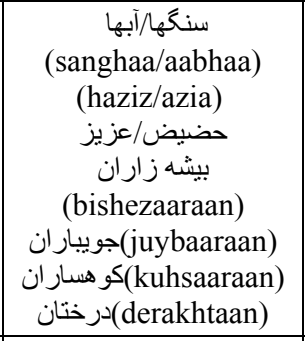 & $\begin{array}{c}\text { Which/Ditch/rich side/ } \\
\text { Abide Prize/otherwise } \\
\text { red/instead }\end{array}$ & 9 & 8 \\
\hline 3 & - & $\begin{array}{l}\text { Ridiculous/worthless } \\
\text { way/stay } \\
\text { Will/still ahead/fed }\end{array}$ & 8 & 0 \\
\hline 4 & 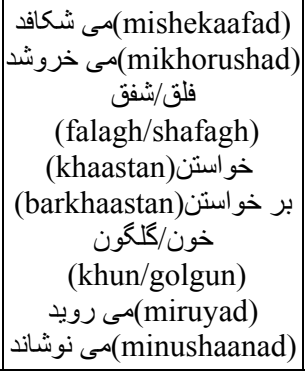 & \begin{tabular}{|c} 
\\
View/you \\
satiate/straight \\
Through/do skies/rise
\end{tabular} & 8 & 10 \\
\hline 5 & 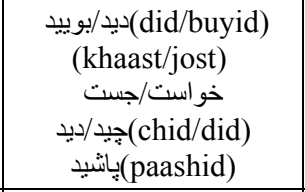 & $\begin{array}{c}\text { Seen/mean } \\
\text { Twilight/night/bright } \\
\text { Divinity/reality } \\
\text { whoever/finger } \\
\text { Say/ray you/true }\end{array}$ & 13 & 7 \\
\hline 6 & $\mid \begin{array}{c}\text { شجاعت(shojaa'at) } \\
\text { (haghighat/ } \\
\text { sedaaghat) }\end{array}$ & $\begin{array}{c}\text { Me/baby courage/edge } \\
\text { Will/still high/sky/eye } \\
\text { History/humanity } \\
\text { sea/see }\end{array}$ & 13 & 3 \\
\hline
\end{tabular}




\subsubsection{Tropes}

Among the characteristic features of a piece of poetry, modern and classic alike, are the literary devices or 'purple patches' used by poets to create novel images and attain desired effects. Examples are metaphor, simile, metonymy, personification, etc. The tropes employed in the Persian and English texts here are specified and explained below with the aim to show what is kept intact, altered, or lost in the process of translation.

\subsubsection{First stanza}

The first stanza includes the following tropes: personification of "trees" standing straight in "honor", personification of "dignity", embarrassed and colored crimson by blood, metaphorical use of "aurora" as a mirror holder, and metaphorical use of "dawn" as an "altar".

On the whole, this stanza is a literal-semantic rendering of the source text which is itself communicative in nature. Words are simple, understandable, and familiar. Yet despite the simplicity of the lexis, there are meaning suggestions and cultural implications that need to be expanded here. The first point to mention in the TT is the word "lover", equivalent for /dust midaaram/) "دوست مي دارم", which has much more semantic load than the original. The Persian speaker simply asserts that he likes or admires trees, whereas the TT shows a greater degree of interest and fondness. The next issue is the personification of "trees" as human beings who stand straight in honor of "you", the addressee of the speaker, "Hosain". Reversely, the phrase "standing straight" does not exactly convey the meaning of (/ghiaam kardan /) قيام كردن". In fact, this word in Persian has two meanings: on the one hand, it means "to stand" and on the other hand, it suggests a sense of "movement or revolution". The second meaning obviously cannot be elicited from the verb "stand" in the 
TT; therefore, the word "rise" is suggested which includes both meanings. Moreover, in Persian the word (/nejaabat/) "نجابت" means both the quality of not behaving in a way that is sexually attractive and being of a noble descent. But the word "modest" only reflects the first meaning. It is not clear which of the two meanings was intended by the poet and, therefore, the use of the word "modest" seems to be just the translator's own impression.

\subsubsection{Second Stanza}

The second stanza incorporates the following figures of speech: personification of the "Pit" in the "Pit which has sucked your blood", paradox of sublimity and lowliness in "elevated Ditch", hyperbole of the breach in "the sword which struck your throat", metonymy in "stones, mountains, streams, and groves" standing for people, symbolic application of "blood" and "red", and metonymy of "sword", "blood" and "red" as criterion for justice.

This stanza is a semantic, communicative and partly pragmatic translation of the original text. Talking from a lexical point of view, the vocabulary is overall simple and familiar; words like "Pit", "elevated Ditch", "lowliness", "rich", "sword", "cut", and "neighbor" are tangible evidences. These words may not exactly match their original counterparts from the point of view of the level of difficulty. For instance, the word (/haziz/) "حضيض" has been translated as something akin to "lowliness", while other words in English can better convey the intended meaning. A good example would be "nadir" which is suggestive of a very low place. There are, at the same time, some words which can not be regarded as simple or familiar like "foe", "abide", and "gush" which are more literary than their original forms and have a greater aesthetic efficacy in comparison with the aforesaid terms.

As to inconsistency in choosing lexical items for the same concept, the first example is "Pit", where the translator has used 
"Pit" once and "Ditch", its synonym, twice for (/godaal/) كودال. It seems that it is more poetic to use "Ditch" in all instances, since it would add to the alliterative effect and the musicality of the translation.

Regarding emphasis, in the second part of the stanza, the line "cut everything in the universe" is not as emphatic as the source text

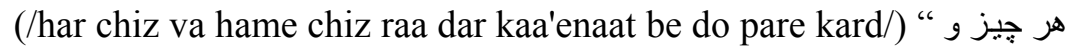

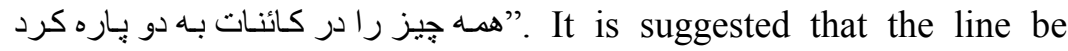
changed to "cut all and everything in the universe". The same is applicable to a similar line in the fourth section of the stanza which can appear as "split all and everything in the universe".

As for the third section of the stanza, "neighbor" has been chosen by the translator for the original (/maayim va/) " ماييم و", something like "there we are" in English, which is of course more interpretive but not more literary than the original. In this section, there are two instances of zero translation as well, i.e. there are no English equivalents for "ماييم و آبها" and " درختان ". The use of “in prize" in line two is an explicitation of the original which is not aimless: on the one hand, it serves as an interpretation; on the other, it is rhymed with "otherwise" in line four.

In the last part of this stanza, the pronoun, "which" has been omitted in, "the blood [which] gushed from your throat split everything in the universe in two". This has made the line shorter but more complex. In the same line, "split" has been used instead of "cut" which is more literary but since it begins with the sibilant /s/, it causes the line to be more euphonic than "cut everything in the universe"(line ten of this same stanza), sounding harsher. In the last line, the word "instead" is an addition which causes a greater degree of emphasis in comparison with the ST and, at the same time, is rhymed with the preceding line: "is either red". 


\subsubsection{Third Stanza}

The third stanza possesses the following tropes: metaphorical application of "death" as a "measure", personification of "life" ridiculed by "death" and yearning for "dying that way", ambiguity of "in reality" used both as a noun phrase and an adverbial, implicit image of a scale on pans of which "blood" and "blood-worth" stand at the same level, and metaphorical application of "blood" as approval of truth.

This stanza is a semantic, communicative and partly pragmatic rendering of the ST. Words like "ridiculous", "worthless", "pity", "secured", "moving ahead", and so forth demonstrate that the lexis used here is simple, familiar and somewhat abstract. Regarding congruity between the ST and the TT, it can be contended that "rendered" is more difficult, powerful and effective than the original ( $/$ kard/) " كردد". In the third line, the word "pity" implies feeling of sympathy and sadness for others' suffering, while the word (/ghebte/) "غبطـ" in Persian is a positively constructive term which means wishing to do like others without envy. Thus, using the compound, 'grudging emulation' seems to be the most appropriate equivalent with the same connotation as the original term. It should also be noted that "secured" in the second part of the stanza is not as powerful in meaning as its Persian equivalent. "Vouched" seems to be a more appropriate choice. Likewise, "moving ahead" is not a precise semantic translation of the noun (/davaam/) "دوام" in the ST. It seems to be a pragmatic rendering of the original because the durability of the world requires a sort of dynamic motion which the translator has tried to convey here through "moving ahead". It has also been used to rhyme with "fed", which means that here musicality has been the priority of the translator. In the same way, "stand still" can not be counted as an exact literal-semantic translation of (/mipaashad/) " مس يانشد" in the ST. This is again justifiable if one interprets the shattering of the world as its death 
and inertness. This is actually an interpretive translation of the original. As for tropes, the image or metaphor of touchstone is again pointed out but this time through "death" as a "measure". The word "measure" is a very appropriate choice since it exactly conveys the intended meaning, i.e. a criterion for discretion of truth and prevarication. The next figure, the personification of life as "ridiculous" has been transferred faithfully, yet the word "ridiculous" is not as loaded and literary as its original (/sokhre/) “ "سخره". Perhaps a more literary choice would be "ludicrous". The next trope is the ambiguity of the phrase "in reality" as both a noun phrase and an adverbial. If the phrase is taken as a noun phrase, "blood" and "blood-worth" will be identical because both of them stand in reality. If it is taken as an adverbial, the meaning will be different, i.e. "blood" really stands at the same level as "bloodworth", which is also logical and acceptable. Finally, in the last line of the stanza, the real image of blood as the approving sign of truth or honesty has been transferred through a different image; namely, "blood"- feeding honesty. Though the source image has changed in translation, it still pertains to Newmark's (1988) second procedure of translating an ST metaphor by replacing it with another metaphor in the TT. In this sense, the intended meaning and the aesthetic features of the ST has been safely preserved and conveyed through another metaphor which is quite different from the original metaphor. Overall, the translation of this stanza is somehow more unfettered in its choice of lexis and tropes.

\subsubsection{Fourth Stanza}

This stanza includes such tropes as: metonymy of symbolic and abstract concepts such as "plants", "waters", "stones", "swords", "lions", "aurora", "dawn", "man's will”, "steadfastness", "discretion of truth and injustice", "valor", "martyrdom", "self-sacrifice" for God's sake, and "iron will", metaphorical use of "stones" as 
stalwartness, metaphorical application of "dawn" as "blood's smile", and symbolic use of sanguine and blood-red colors.

The fourth stanza has been translated semantically, communicatively and partly pragmatically. The vocabulary is again a simple and familiar one, comprised of both abstract and concrete terms like "honesty", "man's will", "plants", "stones", "swords", "lions", and so forth. A contentious word in this chapter is "satiate". This means to give somebody so much of something that (s)he does not feel wanting it anymore (Oxford Dictionary, 2006) which is connotative of giving more in spite of somebody's unwillingness. It is thus quite different from the ST word, (/minushaanad/) "مي نوشاند", but it has been used by the translator for the sake of making rhyme. Reversely, the phrase "standing straight" is quite weaker in meaning than its source form (/istaadegi/) "ايستادكي", since the latter connotes outstanding vigor of body, mind, and spirit which is lost in the TT. A more appropriate choice would be "staunchness" which still implies the manner of standing rather than the spirit of the action. Finally, in the last part of this stanza, "in skies" is an addition only serving to rhyme with the final line: "skies/rise". The last two lines have been pragmatically translated. This enhances the TT readers' knowledge of the implicit aspects of the source text.

Figuratively viewed, all the images and tropes have been effectively and communicatively translated, except for the conceptual metaphor of "stones" (STONE IS STAUNCHNESS) which is lost in translation.

\subsubsection{Fifth Stanza}

In this stanza, we see the following tropes: metonymy of "corn poppies", "flowers", "the Sun", "twilight", "breeze", "bowers", etc., allusion to Moses' miracle of the White Hand, metaphorical use of "eternity" as a mirror reflecting man's lofty stature in will, understatement of the Sun in "of your glance, it's but a ray", and 
personification of "reality".

This stanza is a semantic and communicative translation of the source text. Compared with the vocabulary of the preceding stanzas, the lexis here is relatively more difficult, loaded and literary. Examples are "corn poppies", "twilight", "offshooted", "breeze", "bowers", "protrudes", and "ray". Connotations play a very important role in this stanza. (/Shaghaayegh/), for instance, is connotative of martyrdom, blood and self-sacrifice in Persian culture, but perhaps this is not true with "corn poppies" in Western culture.

\subsubsection{Sixth stanza}

In the sixth stanza, the following figures of speech are used: personification of "courage" as a lonely person, personification of history as a conscientious person, implicit metaphor of a powerful plant "fortified" in the soil for Imam Hosain's valor, metaphorical use of "sincerity" as the most "sweet and lovely" smile, personification of "will" on whose lips there is a sweet and lovely smile, metaphorical application of "intellect" as a baby, idiomatic use of hat falling from the head of intellect as a means to convey man's incapability to understand the greatness of Imam Hosain, personification of "intellect" as a person wearing a hat, understatement of the "intellect," use of the conceptual metaphor: HISTORY IS A PATHWAY, use of the conceptual metaphor: BLOOD IS A SEA, and use of the conceptual metaphor: CULTURE IS A DRINK

This last stanza is a literal-semantic and communicative rendering of the ST. Here, the words used such as "courage" and "conscience" are simple, familiar and mostly abstract. Only the term, "lofty" does not seem appropriate, since it does not transfer the entire meaning of (/tanaavar/) "تتناور". Another meaning of this Persian word is "strong", or "sturdy", which has not been conveyed 
through the chosen English equivalent.

As for the figurative use of language, this stanza is unique among other stanzas. The tropes used in the source text here have all been literally translated into English to create the same meaning and effect in the target language, though some tropes, as mentioned above, are so novel in the ST that they require the TL readers to acquaint themselves with Persian literature and Islamic culture in order to grasp the real suggestions and images intended.

\subsection{Extra-textual Analysis}

In the previous section, the ST and TT were examined at textual level-one side of the coin. The other side is a comparative consideration at extra-textual level with regard to the pragmatics of the source and target texts. At this level, coherence and implicature are the elements to be discussed. Here the main focus is the knowledge presented in the ST as well as the TT reader's knowledge of the world; that is to say, the cultural aspects of the text.

Translation of a text inevitably involves at least two cultures. According to Javaherian (1992), if it is accepted that one of the purposes of literary translation is to make the reader acquainted with other nations' cultures in other parts of the world, then translation of cultural values and concepts of a literary work becomes inevitable. This is because, he adds, culture and language are essentially so much interwoven and indivisible that meaning transference is impossible without transference of cultural concepts. Therefore, the translator is to introduce such values and concepts rather than replace them with the target language ones. In fact, it is quite natural that the TT reader whose culture is definitely different from that of the ST writer may feel some gaps in the TT, or may be unable to glean at least some parts of it. This is especially peculiar to culturebound texts that have deep roots in the SL culture, allusive of historical figures, myths, events and ethics of that culture missing in 
the TL culture. But what should be done to fill or attenuate the nebulous feature of such gaps? Based on what James (2002) believes, in translating a text, the translator should consider for whom the original text was destined and whether his/her readership corresponds to the potential TT reader. Thus, problems of translation of a text, James adds, are not merely of a purely lexical character but also of a social, economic, political and cultural context as well as connotative aspects of a more semantic character. The remedy to such problems lies in using either of the two seemingly contradictory methods proposed by Newmark (1988), i.e. "transference" and "componential analysis". Transference gives "local color" to the text by preserving cultural names and concepts. Still, the method may be problematic for the general readership through restricting the comprehension of particular aspects of the ST. Componential analysis is described by Newmark (1988) as the most accurate translation procedure, which excludes the culture and highlights the message. One can however prognosticate the results of both proposed methods to be somehow extreme. As for the first method, the TT reader will not understand parts of the intended meaning and cultural concepts of the ST writer. In contrast, even if the TT is comprehensible to the TT reader, through the application of the second method, part of the aesthetics of the text will be impaired. It seems desirable therefore that the translator should benefit from a synthesis of the two methods.

Regarding Garmaroodi's poem in this study, it is to a large extent culture-bound. The theme is glorification of Imam Hosain (the third Shiite Imam), which is indivisible from specific reference to other relevant issues like his mother's marriage gift (i.e. water), his lethal thirst, his bloody martyrdom by Yazid, his being decapitated, and the location of his martyrdom (the elevated Ditch). Since the English rendering is mostly a literal-semantic translation of the original, virtually all of the cultural words have been literally transferred, and no explanation has been provided for them except 
for the name Yazid who is recognized as a foe in the second stanza. This is in part justifiable because the symbolic and mythical aspects of blood-red corn poppies, aurora and dawn, for instance, cannot be easily transferred to the target language. Here, color imagery plays an important part in conveying the sense or the meaning. Red is the prevalent color in the first stanza. Personification of the abstract idea of "dignity" has been very beautifully conveyed through the use of this color which suggests that the idea of "dignity" is always somehow related to red or crimson in Persian. Moreover, "aurora", a natural phenomenon, is closely interwoven with redness of blood and consequently corresponds to the important concept of sublimity of martyr's blood, his modesty and faith, in Islamic culture. It is by no means guaranteed that the English readers can appreciate such aesthetic values in the same way as the Muslim Persian readers do, because the color red or crimson in English is often connotative of love or passion and this indeed contrasts with the intended meaning. The TL readers will confront the same problem in respect to the concepts of "water" and "marriage gift", for they most probably know nothing about Imam Hosain's mother and the story of her marriage gift (i.e. water). The word "مهر"(/mahr/) has religious and, especially in this case, sacred connotations which have not been conveyed to the TL readers by simply using the compound "marriage gift". In like manner, "water" which is in the ST mentioned as Fatima's (the Holy Prophet's daughter) dower has connotations such as purity, faith, innocence and God's bounty which are absent in English culture. And, too, he may not know that Imam Hosain and his reverend family, relatives and companions were absolutely deprived of the same water in the landmark war of Karbala. What the TT readers may know about the connotations of water can be "life", "spiritual mystery and infinity" or "death and rebirth" (Guerin 1999), which seems insufficient for understanding the "water" referred to in the Persian poem, of which alludes as well to the water Imam Hosain was deprived when martyred. 
Another example of culture specificity lies in the phrase, "And Yazidi, whatever/ with your foe abide!" in the second stanza, which has been translated pragmatically. Here, the speaker is distinguishes between Hosaini and Yazidi: one related to Imam Hosain and whatever on his side(a divine concept) and the other to Yazid and his mean subordinates who martyred Imam Hosain mercilessly. The ST readers know very well about this dichotomy, whereas the TT readers may not have a tinge of information about the issue. Still another example can be seen in the second section of the fifth stanza, with a very beautiful allusion to the miraculous White Hand of Moses. This too, causes a great loss of meaning in a literalsemantic translation and may even lead the TT readers to raise a question about the irrelevancy of this image to the whole text. This is because the allusion of Moses' White Hand has been delicately and intricately woven into the image of blood dripping from the fingertips, meaning that white light would no longer emit from the hand of the truly faithful and divine men; instead, blood will gush out of such hands as it gushed from the body of Imam Hosain. This is a novel metaphor used by the poet, which should first be precisely understood and then accurately and "only" pragmatically translated for the creation of the same image and meaning in the target language.

In the last stanza, there are abstract terms with connotations which make them bound to the SL culture. The word "culture", for instance, is not simply related to a social system, a code like decorum or ethics. It implies some concepts beyond society in its Islamic sense; it pertains to the divine values of humanity, the way of being a real human being, the way of loving the only Creator of the worlds and the way of sacrificing the dear and at the same time worthless self for His sake. This is what Imam Hosain tried to gift to humanity. Therefore, those TT readers who are not familiar with Islamic culture will not receive the communicative effects of the original text unless they try to get more information about the SL 
culture.

The final section of the last stanza gives a Utopian perspective of humanity passing the course or pathway of history, being slaked by Imam Hosain standing heroically at the pool of his flowing blood with a cup of culture and human values for those who are zealous and thirsty for the paramount value of martyrdom. Here, the image of "saki" (i.e. cup-bearer in sacred mystical culture) is quite effectively transferred.

Based on the above discussion, the literal-semantic translation of Garmaroodi's poem in this study is more reader-oriented and, therefore, lacks perfect coherence (in the sense of incorporating the TL readers' knowledge of the world and the knowledge presented in the source text) at the extra-textual level.

\section{Results and Conclusion}

The source and target texts were analyzed both at the textual and extra-textual levels. With reference to the analysis at the textual level, different aspects of form including tropes, rhyme and music were examined. Also tone and content of the texts were studied. As for the form, the translated piece is in its totality a non-systematic rhymed ode with a fluctuating stanza pattern. Furthermore, it incorporates the most prevalent structural patterns in the ST, such as present perfect, past tense verbs, relative clauses (which-clauses) and clauses with Such/So, etc. Finally, the rhythmical aspects of the TT render it to a more literary and beautiful piece than the original, though in some cases the constrictions of rhyme seem to be forced. Concerning the music of the text, the translator has been able to create appropriate alliterations in the TT, although the patterns are not necessarily identical with those of the ST. Figuratively viewed, the images and symbolic elements of the ST have been literally and, in rare cases, pragmatically translated into English. As an example, 
the symbolic concepts of "blood" and "red" which are quite dominant in the ST, creating an implicit image of a touchstone that separates innocence, purity and true valor from tyranny, villainy and false pride, have been keenly retained in the TT. Generally speaking, all the figures of speech such as metaphor, personification and sensestygia have been well-preserved in the TT.

The translation of the third stanza is somehow more unfettered in its choice of lexis and tropes. In the fifth stanza compared with the vocabulary of the preceding stanzas, the lexis is relatively more difficult, loaded and literary.

The tone of the poem is lyrical, admonitory, serious, heroic and religious, which has been preserved in translation. The message of the poem is to invite the reader to a greater truth behind the surface glorification and praising. The poem is descriptive and demonstrates the great character of Imam Hosain who turns out to be an eternal myth in Muslim culture and non-Muslim history. All this has been literally rendered into English and perception has been left to the TT reader.

With respect to the analysis at the extra-textual level, the TT is mostly author-oriented, lacking perfect coherence at this level. Researchers in this study, therefore, suggest that cultural concepts should be translated literally but supported by explanatory annotations. This way, the authenticity and aesthetic aspects of the ST will both be kept intact and the TT readers' comprehension of the translated text will be enhanced.

As for final words, on the one hand, rhyme scheme, music, lexis, figures, aura and message (some of which touched in this study at the textual analysis section above) contribute to the emotional impact of the translated text which, in turn, brings about its logical and emotional appeal. On the other hand, the pragmatics of the text, i.e. coherence (the knowledge presented in the text through linguistic elements versus the reader's knowledge of the world influenced by his/her age, sex, race, nationality, education, religion and political 
ties) and implicature (non-conventional implied meanings), give rise to the real meaning of the text. Thus, it is proposed that the following tentative models be employed in the analysis and assessment of poetic translations. These models are by no means considered exhaustive; rather, they are subject to proper refinement based on fresh findings. 


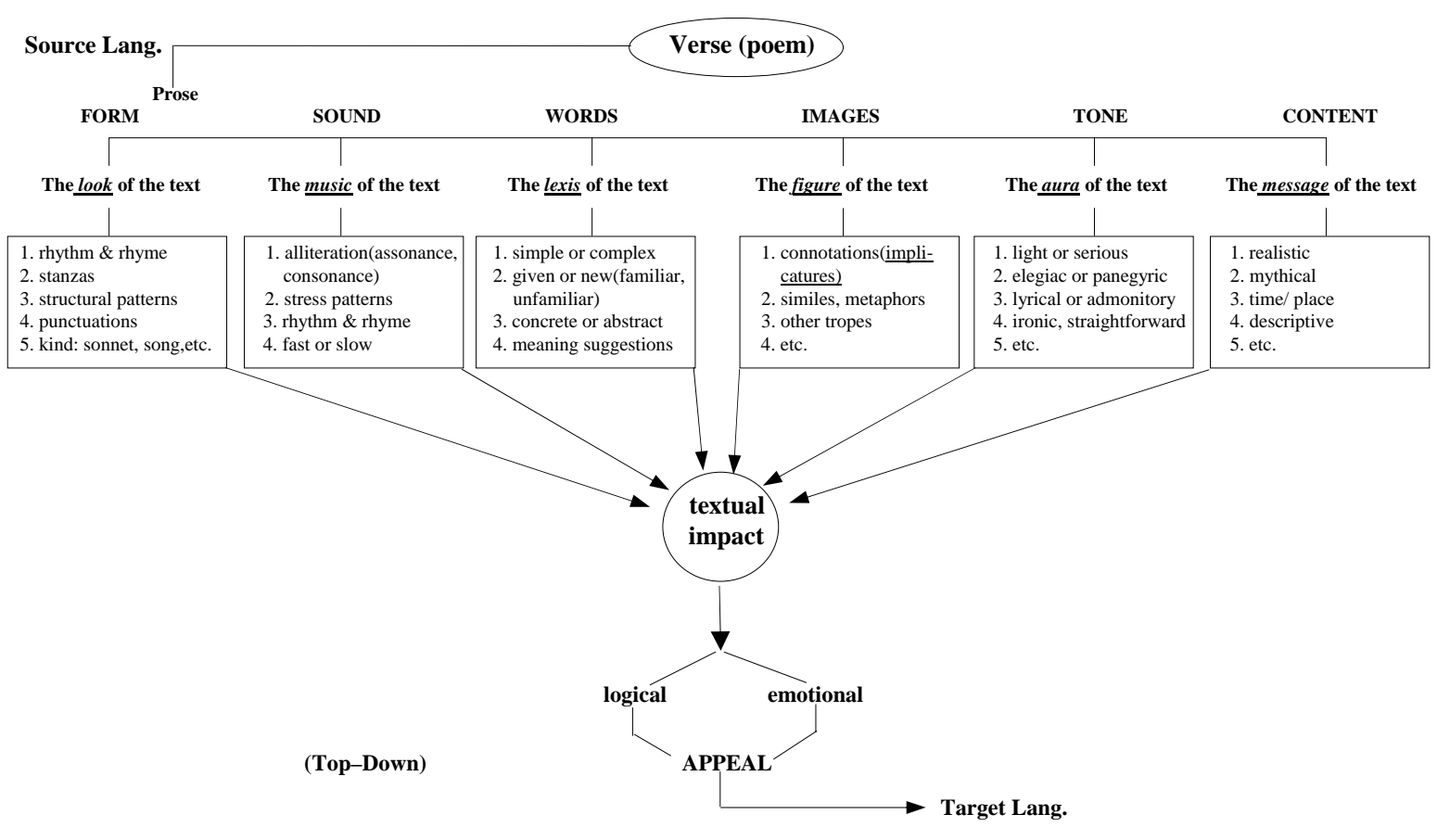

Figure 1. A Tentative Model of Poetic Translation Analysis and Assessment: Textual Level 


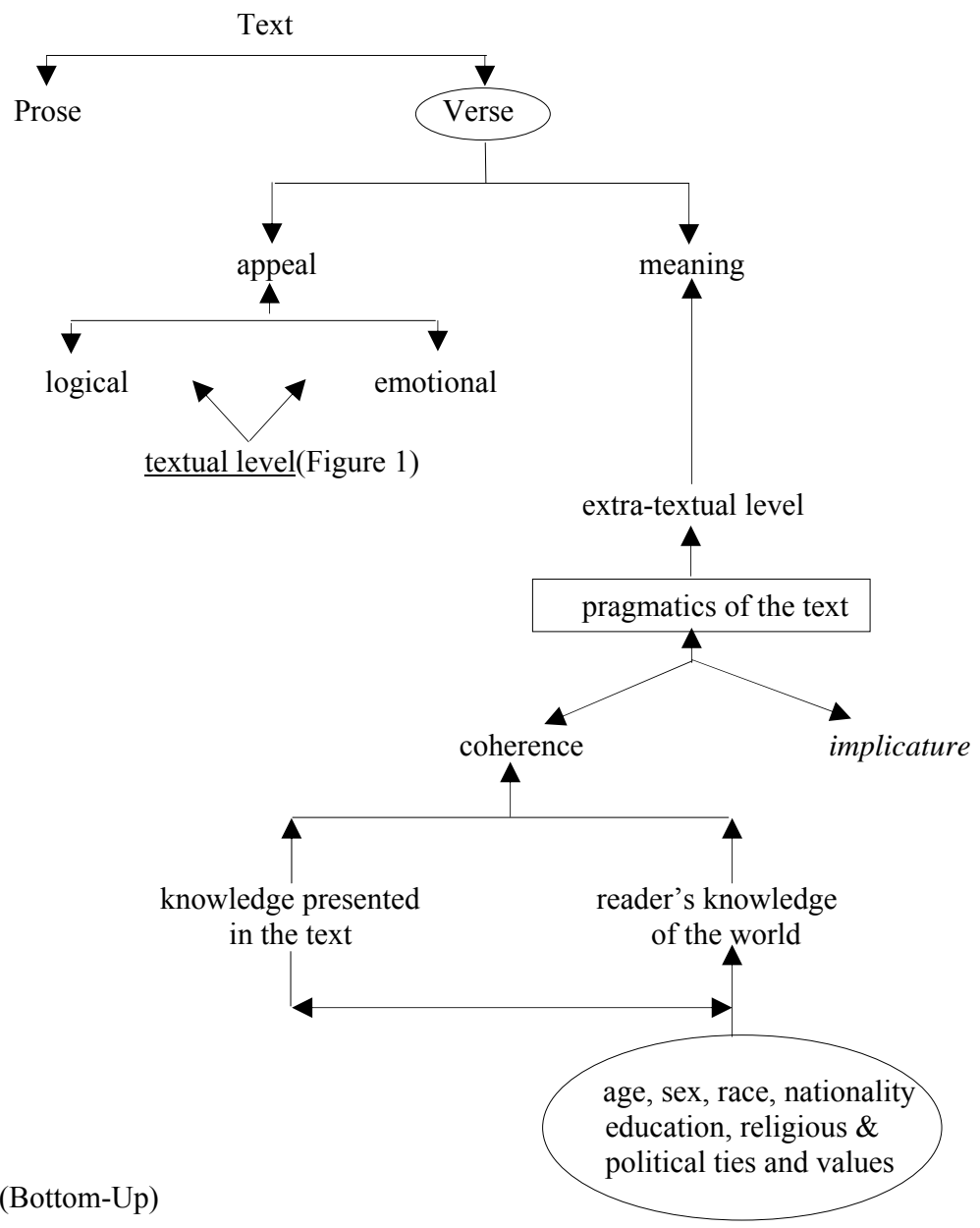

Figure 2. A Tentative Model of Poetic Translation Analysis and Assessment: extra-textual Level 


\section{References}

Abbasi, J. \& S. Manafi. 2004. Strategies of Poetry Translation: Reconstructing Content and Form. Translation Studies 1.4.

Abrams, H. 1993. A Glossary of Literary Terms. Orlando, FL: Harcourt Brace College Publishers.

Arberry, J. 1947. Fifty Poems of Hafez. Cambridge: Cambridge University Press.

Catford, C. 1965. A Linguistic Theory of Translation. London: Oxford University Press.

Connoly, D. 1991. Poetry Translation, In M. Baker (ed.), Routledge Encyclopedia of Translation Studies 1998. London \& New York: Routledge.

Francis, R. 2006. Unlocking the Black Box: Researching Poetry Translation Processes. In M. Perteghella \& E. Loffredo (eds.), Translation and Creativity 59. London: Continiuum.

Friedberg, M. 1997. Literary Translation in Russia: A Cultural History. University Park, PA: Pennsylvania State University Press.

Frost, W. 1969. Dryden and the Art of Translation. New Haven, CON: Yale University Press.

Giblett, R. 1987. Translating the Other: Nobakov and Theories of Translation. Babel 3.

Guerin, W. et al. 1999. A Handbook of Critical Approaches to Literature. New York: Harper \& Row Publishers.

Holmes, J. (ed.). 1970. The Nature of Translation: Essays on the Theories and Practice of Literary Translation, The Hague \& Paris: Mouton.

James, K. 2002. Cultural Implications for Translation. Available at URL $<$ http://accurapid.com/journal/22delight.htm $>$.

Jacobson, R. 1960. Closing Statement: Linguistics and Poetics. In T. Seboek (ed.), Style in Language 350-77. Cambridge, MA: MIT Press.

Javaherian, S. 1999. The Effect of Cultural Elements in Literary 
Translation Analysis: A Critical Study on Alice in Wonderland. Motarjem 2, 29-34.

Keyvani, M. 2001. Reflections on Theories and Principles of Persian Mystical Poems. Translator Quarterly 10.34.

Lefevere, A. 1992. Translation, History, Culture: A Source Book. London \& New York: Routeledge.

Manafi Anari, S. 2001. Approaches to the English Translation of Literary and Islamic Texts (II). Tehran: SAMT.

Mollanazar, H. 2005. Principles and Methodology of Translation. Tehran: SAMT.

Munday, J. 2002. Introducing Translation Studies. London \& New York: Routledge.

Musavi Garmaroodi, A. 1984. Khatte Khun. Tehran: Zavvar Publications.

Nair, K. 1991. Translating Poetry: Some Basic Problems. International Journal of Translation 3. 1 \& 2, 90-97.

Newmark, P. 1988. Approaches to Translation. New York: Prentice Hall. . 1988. A Textbook of Translation. New York: Prentice Hall.

Nicholson, R. 1962. Translations of Eastern Poetry and Prose. Cambridge: Cambridge University Press.

Pope, A. 1711. An Essay on Criticism. Available at URL <http:// classiclit.about.com/library/bl-etexts/apope/bl-apope-essaycrit. htm>.

Rehatsek, E. 1964. The Gulistan of Sa'di. London: George Allen \& Unwin LTD.

Toury, G. 1978. The Nature and Role of Norms in Translation. Cited in James's Cultural Implications for Translation. Available at $<$ URL http://accurapid.com./journal/22delight.htm $>$.

Vahid Dastjerdi, H. 2006. East of Sophia. Qum: Ansaryan Publications. 
38 Towards a Practical Model for Translation Analysis and Assessment of Poetic Discourse

\section{Appendix}

\section{Target text}

$1 * * * * * *$

Of trees am I a lover

Standing straight in your honor

And of water...

The marriage gift of your mother.

Your blood's colored dignity red;

Aurora mirrors your modesty,

And dawn's an altar,

Wherein martyrdom morning prayer

You've said!

$2 * * * * * *$

That Pit I recall which

Has sucked your blood-

A very elevated Ditch,

In which one can be dear,

Though of lowliness

It is rich!

The sword

Which struck your

Throat,

Cut everything in the universe

In two:

Hosaini, what'er on your side;

And Yazidi, what'er

By your foe abide

Now, neighbor to stones are we,

Mountains, streams and groves,

Some of which being Yazidi in prize,

But Hosaini, if otherwise!

The Blood

Gushed your throat,

Split everything in the universe

In two-

And now, everything

Is either red,

Or not Hosaini, instead!

\section{Source Text}

$1 * * * * * *$

درختان را دوست ميدارم

كه به احترام تو قيام كرده اند

و آب را

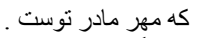

خون تو شرف را سرخكون كرده است!

شفق آيينه دار نجابتت

و فلق مهر ابي

كهن نو در آن

نماز صبح شهادت كذارده اي!

$2 * * * * * *$

در فكر آن كَودالم

كه خون نو را مكيده است!

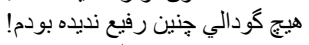

آري در حضيض هم مي توان عزيز بودئ

از كوّدال بيرس!

شمشيري كه بر كلوي تبو آمد

هر جيز و همه جيز را در كائنات

به دو باره كردات

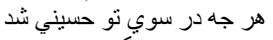

و ديكُر سو بزيدي!

اينك ماييم و سنغّيا.

مايييم و آبها

درختان/كو هسار ان/جويبار ان/بيشه زاران

وكرنه حسيني اند!
خوني كه از كلوي تو نر اويد

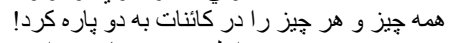

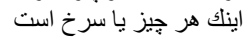

يا حسيني نيست! 
$3 * * * * * *$

Oh! Your death a measure!

Your death made life so ridiculous,

And rendered it so worthless

That dying that way,

Turned out to stay!

In reality, your blood,

With your blood-worth

At the same level stood

And your iron will

Secured world's moving ahead,

For world with lies stands still,

Your blood, but honesty fed.

\section{$4 * * * * * *$}

In honesty should we view,

And in growing plants,

The visage of you.

In waters

When satiate,

In stones,

Standing straight!

In swords,

When cutting through,

And in lions,

Roaring as they do!

In Aurora, sanguine in skies,

In dawn, blood's smile,

In man's will,

And in his rise!

\section{5******}

In corn poppies you must be seen

In flowers smelled,

And in the sun sought,

Do I mean!

You must be seen in twilight, Offshooted from night,

Scattered through breeze,

Picked up from bowers bright!

You must only be seen in Divinity.

His hands whoe'er, whene'er,

Protrudes the sleeves of reality,

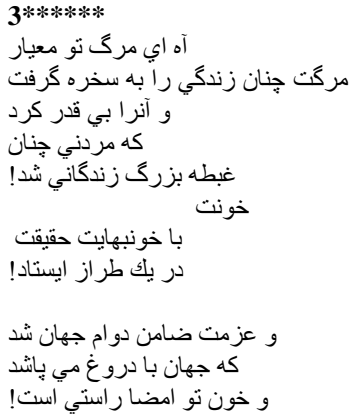

\section{$4 * * * * * *$}

تو را بايد در راستي ديد

و در كياه

در آب هنگامي كه مي رويد!

وقتي مي نوشاند!

در سنى نو مناندا

جون ايستادكي ست!

در ششير آن زمان كه مي شكافد

و در شير مئر

كه مي خروشد!

در شفق كه كلاًّون است

در فلق كه خنده خون است!

در خون استن

بر خواستن!

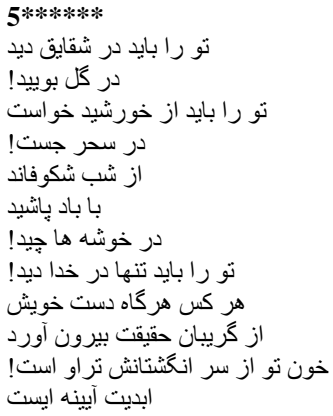


40 Towards a Practical Model for Translation Analysis and Assessment of Poetic Discourse

Gushed your blood from his finger!

Eternity mirrors

The lofty stature of you

In will!

The Sun deserves not, 'tis true,

If so, would I dare to say:

Of your glance, it's but a ray!

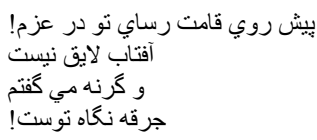

6******

At history's conscience shining edge,

To safeguard the truth,

You've fortified your root!

And Sincerity,

On the lips of your will,

Sweet and lovely,

Stands still!

You're so lofty and high

That raising the head to sky,

Your stature to eye,

Falls off the head, the hat of me,

Of intellect.... baby!

At the pathway of history,

On your blood's fathomless sea,

$6 * * * * * *$

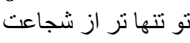

در كوشه روشن وجدان تاريخ

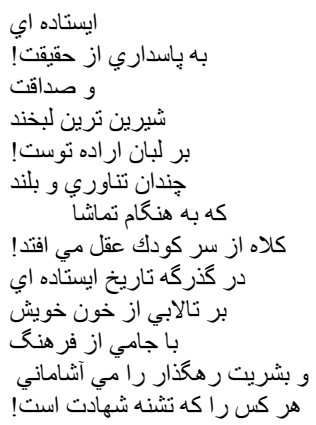

To quench the thirst of passing humanity-

The thirsty of martyrdom, I see! 